\begin{tabular}{|c|c|c|}
\hline \multirow{3}{*}{$\begin{array}{r}\text { Case Reports in } \\
\text { Gastroenterology }\end{array}$} & \multirow{2}{*}{\multicolumn{2}{|c|}{ Case Rep Gastroenterol 2016;10:769-774 }} \\
\hline & & \\
\hline & $\begin{array}{l}\text { DOI: } 10.1159 / 000452757 \\
\text { Publisned online: December 13, } 2016\end{array}$ & $\begin{array}{l}\text { (c) } 2016 \text { The Author(s) } \\
\text { Published by S. Karger AG, Basel } \\
\text { www.karger.com/crg }\end{array}$ \\
\hline & \multicolumn{2}{|c|}{$\begin{array}{l}\text { This article is licensed under the Creative Commons Attribution-NonCommercial } 4.0 \\
\text { International License (CC BY-NC) (http://www.karger.com/Services/OpenAccessLicense). } \\
\text { Usage and distribution for commercial purposes requires written permission. }\end{array}$} \\
\hline
\end{tabular}

\title{
Colorectal Cancer Associated with Streptococcus anginosus Bacteremia and Liver Abscesses
}

\author{
Umair Masood Anuj Sharma Dhruv Lowe Rashad Khan \\ Divey Manocha \\ Department of Internal Medicine, SUNY Upstate Medical University, Syracuse, NY, USA
}

\section{Keywords}

Streptococcus anginosus · Bacteremia · Liver abscess · Colon cancer

\begin{abstract}
Streptococcus anginosus is part of the normal flora of the human gastrointestinal tract. Their ability to cause abscesses is very unique and sets them apart from the rest of the streptococci groups. While an association of group $D$ streptococcus bacteremia and endocarditis with colorectal carcinoma is well established, $S$. anginosus infections are rarely implicated with colonic malignancy. We present a case of a 62 -year-old male who presented to the hospital with fatigue and generalized abdominal pain. Computed tomography of the abdomen revealed multiple liver abscesses and rectal thickening. Blood cultures were found to grow $S$. anginosus bacteria. Colonoscopy revealed a rectal mass which was later confirmed to be rectal adenocarcinoma. This case presents an association between $S$. anginosus bacteremia and presence of colorectal cancer which has been highlighted in only a few case reports in literature. This should prompt clinicians to screen for colorectal cancer in patients with S. anginosus bacteremia.

(C) 2016 The Author(s)

Published by S. Karger AG, Basel
\end{abstract}

\section{KARGER}

Umair Masood, MD

Department of Internal Medicine

SUNY Upstate Medical University

750 East Adams Street, Syracuse, NY 13210 (USA)

E-Mail masoodu@upstate.edu 
Masood et al.: Colorectal Cancer Associated with Streptococcus anginosus Bacteremia and Liver Abscesses

\section{Introduction}

Streptococcus anginosus is a subgroup of viridans streptococci that are part of the normal flora of the human oral cavity and gastrointestinal tract [1]. Their ability to cause abscesses is very unique and sets them apart from the rest of the streptococci groups [2]. While an association of group D streptococcus bacteremia and endocarditis with colorectal carcinoma (CRC) is well established, $S$. anginosus infections are rarely implicated with colonic malignancy. We present a case of a 62-year-old male with liver abscesses due to $S$. anginosus bacteremia who was found to have rectal adenocarcinoma.

\section{Case Report}

A 62-year-old male with a history of hypertension and type 2 diabetes mellitus presented to the hospital with fatigue and chills for the duration of 2 days. On presentation, he reported vague generalized abdominal pain. His vitals were pertinent for a temperature of $38.4^{\circ} \mathrm{C}$ and a heart rate of $109 \mathrm{bpm}$. On physical examination, he exhibited generalized abdominal tenderness on deep palpitation and tachycardia. His laboratory findings revealed a white blood cell count of $15.410^{6} / \mu \mathrm{L}$ with $82 \%$ neutrophils, blood urea nitrogen of 32 $\mathrm{mg} / \mathrm{dL}$, and creatinine of $1.3 \mathrm{mg} / \mathrm{dL}$. Liver functions tests and coagulation parameters were found to be within normal limits. Two sets of blood cultures were immediately drawn and the patient was started on intravenous (i.v.) fluids and broad spectrum i.v. antibiotics, i.e. vancomycin $1 \mathrm{~g}$ every $8 \mathrm{~h}$ and piperacillin/tazobactam $3.375 \mathrm{~g}$ every $6 \mathrm{~h}$. Computed tomography (CT) of the abdomen revealed multiple hypodense lesions in the right hepatic lobe (Fig. 1), irregular eccentric thickening of the anterior rectal wall measuring $2 \times 2.8 \times 1.8 \mathrm{~cm}$, and enlarged porta hepatis and gastrohepatis lymph nodes. Interventional radiology was consulted for drainage, but the abscesses were deemed unsuitable for drainage due to their loculated characteristics. Both sets of blood cultures resulted the next day growing $S$. anginosus. As per the sensitivity results, the antibiotic regimen was changed to i.v. ceftriaxone $(2 \mathrm{~g}$ every $24 \mathrm{~h}$ ). A transesophageal echocardiogram was found to be negative for any endocarditic lesions. When the patient was more stable, a colonoscopy was performed, which revealed a rectal mass (Fig. 2). Biopsy of the rectal mass confirmed it to be a moderately differentiated adenocarcinoma of the colon (Fig. 3). The patient was discharged after an 8-day hospital course on a total of 6 weeks of i.v. antibiotics and a follow-up with oncology services. Repeat CT scan of the abdomen after the antibiotic course showed resolution of the hepatic abscesses.

\section{Discussion}

The $S$. anginosus group, also known as $S$. milleri, is a group of gram-positive, catalasenegative cocci. They are motile, facultative anaerobes which can have variable hemolytic patterns such as alpha, beta, or gamma [3]. Generally, they are amongst the normal flora of the gastrointestinal and genitourinary tract [1]. This group of bacteria is well known for their pathogenicity and their tendency to form abscesses [2]. Deep tissue and liver abscesses seem to be driven by the production of pyrogenic exotoxins such as intermedilysin [4]. Furthermore, they also produce hydrolytic enzymes such as hyaluronidase that may contribute towards the spreading of the organism [5]. Though they are part of the normal human flora, 
Masood et al.: Colorectal Cancer Associated with Streptococcus anginosus Bacteremia and Liver Abscesses

they can invade in the circulation even without any obvious site of trauma or infection. Infections are usually polymicrobial and can range from minor oral infections such as pharyngitis to major systemic infections resulting in lung, brain, liver, kidney, or soft-tissue abscesses [6]. The mode of treatment for hepatic abscesses usually involves drainage and intravenous antibiotics. Drainage can be done either via percutaneous catheter or needle aspiration. Whereas needle aspiration is preferred for a single abscess less than $5 \mathrm{~cm}$ in diameter, a catheter is preferred for those greater than $5 \mathrm{~cm}$ in diameter [7]. Multiple abscesses and those that are loculated can be considered for surgical drainage. Our patient presented with multiple loculated liver abscesses which were not amenable to nonsurgical drainage. Clinicians in this case opted for a prolonged antibiotic course only which showed an excellent response.

Several bacterial and viral agents have been implicated as risk factors for colorectal carcinoma. Endocarditis caused by group D streptococcus in particular has a well-known association with CRC [8]. While the data on these pathogens themselves being risk factors are conflicting, the association is apparent. It has been proposed that the presence of a cancerous lesion provides an insult to the normal colonic mucosa allowing these pathogens to invade the circulation. Therefore, the bacterial infection is not a risk factor but rather a consequence of CRC [9]. Our patient was found to have $S$. anginosus bacteremia with liver abscesses and was incidentally found to have rectal adenocarcinoma, suggesting a similar association. A literature review revealed only a few case reports showing this relationship. Lin et al. [10] published a case report in the Journal of Cardiac Surgery in which the patient in question had infective endocarditis from $S$. anginosus and was found to have adenocarcinoma of the sigmoid colon. Similarly, Tzur et al. [11] and Millichap et al. [12] published cases in the Israel Medical Association Journal and the West Indian Medical Journal, respectively, in which the patients in question presented with $S$. anginosus liver abscesses and were found to have adenocarcinoma of the colon. In addition, systemic S. anginosus infections have also been reported in patients with esophageal and gastric cancer [13].

In conclusion, our case further validates a relationship between $S$. anginosus systemic infection and occurrence of CRC. Similar to other bacterial species, the association is likely not causative. Nonetheless, the association warrants further studies to validate this finding as it may have further implications, i.e. screening for colon cancer in patients who present with systemic infections caused by $S$. anginosus. As our patient had evidence of malignancy on CT of the abdomen, perhaps radiological investigation could provide an alternative form of colon cancer screening in such patients.

\section{Acknowledgements}

We would like to thank Daniel Zaccarini, MD, for creating the histopathology slides.

\section{Statement of Ethics}

The authors have no ethical conflicts to disclose. 


\section{Case Reports in \\ Gastroenterology}

(C) 2016 The Author(s). Published by S. Karger AG, Basel www.karger.com/crg

Masood et al.: Colorectal Cancer Associated with Streptococcus anginosus Bacteremia and Liver Abscesses

\section{Disclosure Statement}

None of the authors have any conflict of interest.

\section{References}

1 Mejaro B, Edwardsson S: Streptococcus milleri (Guthof); an indigenous organism of the human oral cavity. Arch Oral Biol 1975;20:757.

2 Gossling J: Occurrence and pathogenicity of the Streptococcus milleri group. Rev Infect Dis 1988;10:257.

-3 Ruoff KL: Streptococcus anginosus ("Streptococcus milleri"): the unrecognized pathogen. Clin Microbiol Rev 1988;1:102-108.

4 Nagamune H, Whiley RA, Goto T, Inai Y, Maeda T, Hardie JM, Kourai H: Distribution of the intermedilysin gene among the anginosus group streptococci and correlation between intermedilysin production and deep-seated infection with Streptococcus intermedius. J Clin Microbiol 2000;38:220.

-5 Jacobs JA, Stobberingh EE: Hydrolytic enzymes of Streptococcus anginosus, Streptococcus constellatus and Streptococcus intermedius in relation to infection. Eur J Clin Microbiol Infect Dis 1995;14:818.

-6 Bert F, Bariou-Lancelin M, Lambert-Zechovsky N: Clinical significance of bacteremia involving the "Streptococcus milleri" group: 51 cases and review. Clin Infect Dis 1998;27:385.

7 Zerem E, Hadzic A: Sonographically guided percutaneous catheter drainage versus needle aspiration in the management of pyogenic liver abscess. AJR Am J Roentgenol 2007;189:W138.

$\rightarrow 8$ Burnett-Hartman AN, Newcomb PA, Potter JD: Infectious agents and colorectal cancer: a review of Helicobacter pylori, Streptococcus bovis, JC virus, and human papillomavirus. Cancer Epidemiol Biomarkers Prev 2008;17:2970.

-9 Boleij A, Van Gelder MM, Swinkels DW, Tjalsma H: Clinical Importance of Streptococcus gallolyticus infection among colorectal cancer patients: systematic review and meta-analysis. Clin Infect Dis 2011;53:870.

10 Lin CY, Chao PC, Hong GJ, Tsai YT, Lee CY, Tsai CS: Infective endocarditis from Streptococcus viridans associated with colonic carcinoma: a case report. J Card Surg 2008;23:263-265.

11 Tzur T, Liberman S, Felzenstein I, Cohen R, Rivkind AI, Almogy G: Liver abscesses caused by Streptococcus milleri: an uncommon presenting sign of silent colonic cancer. Isr Med Assoc J 2003;5:206-207.

12 Millichap JJ, McKendrick AI and Drelichman VS: Streptococcus intermedius liver abscesses and colon cancer: a case report. West Indian Med J 2005;54;341-342.

13 Sasaki H, Ishizuka T, Muto M, Nezu M, Nakanishi Y, Inagaki Y, Watanabe H, Terade M: Presence of Streptococcus anginosus DNA in esophageal cancer, dysplasia of esophagus, and gastric cancer. Cancer Res 1998;58:2991-2995. 


\section{Case Reports in Gastroenterology

\begin{tabular}{|c|c|}
\hline se Rep Gastroenterol 20 & :769-774 \\
\hline DOI: $10.1159 / 000452757$ & $\begin{array}{l}\text { (c) } 2016 \text { The Author(s). Published by S. Karger AG, Basel } \\
\text { www.karger.com/crg }\end{array}$ \\
\hline
\end{tabular} \\ Masood et al.: Colorectal Cancer Associated with Streptococcus anginosus Bacteremia and Liver Abscesses}

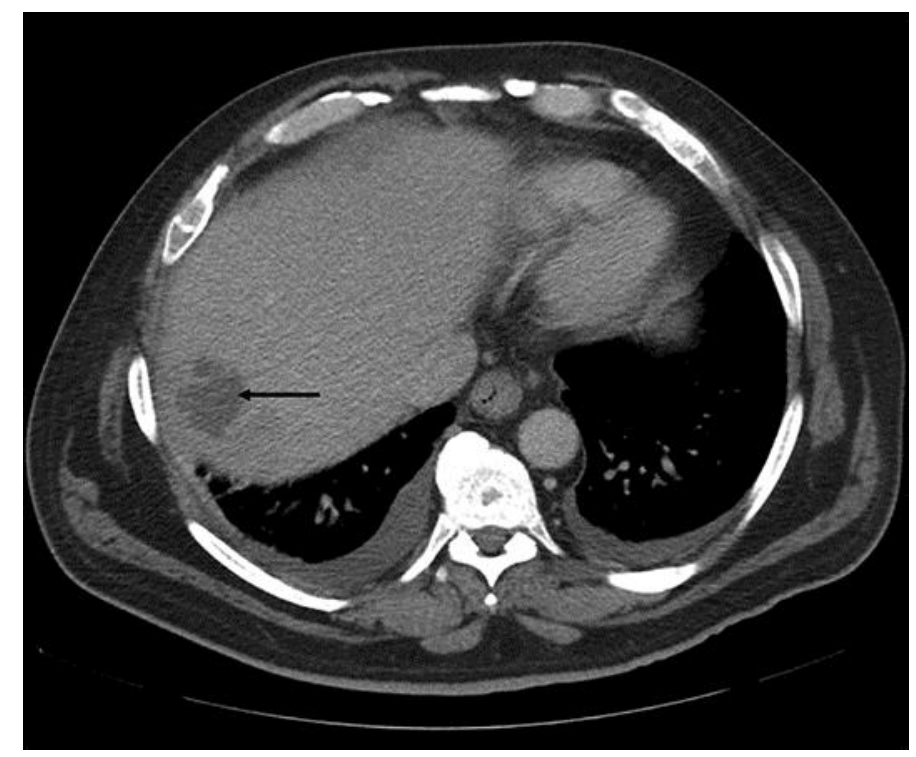

Fig. 1. CT of the abdomen showing 1 of the multiple liver abscesses (arrow).

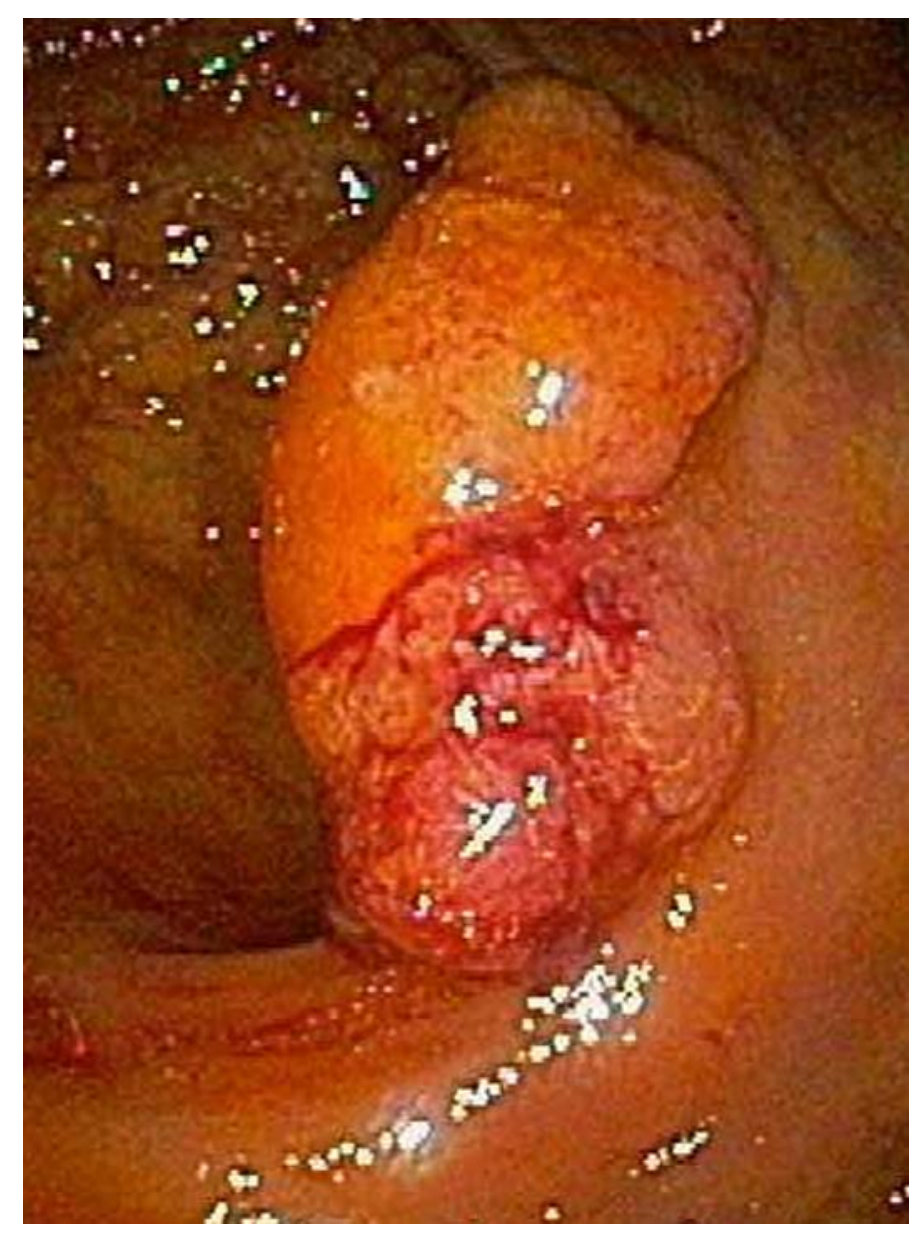

Fig. 2. Colonoscopy image showing a rectal mass. 


\section{Case Reports in Gastroenterology Case Rep Gastroenterol 2016;10:769-774 \begin{tabular}{l|l}
\hline DOI: $10.1159 / 000452757$ & C 2016 The Author(s). Published by S. Karger AG, Basel
\end{tabular} www.karger.com/crg \\ Masood et al.: Colorectal Cancer Associated with Streptococcus anginosus Bacteremia and Liver Abscesses}

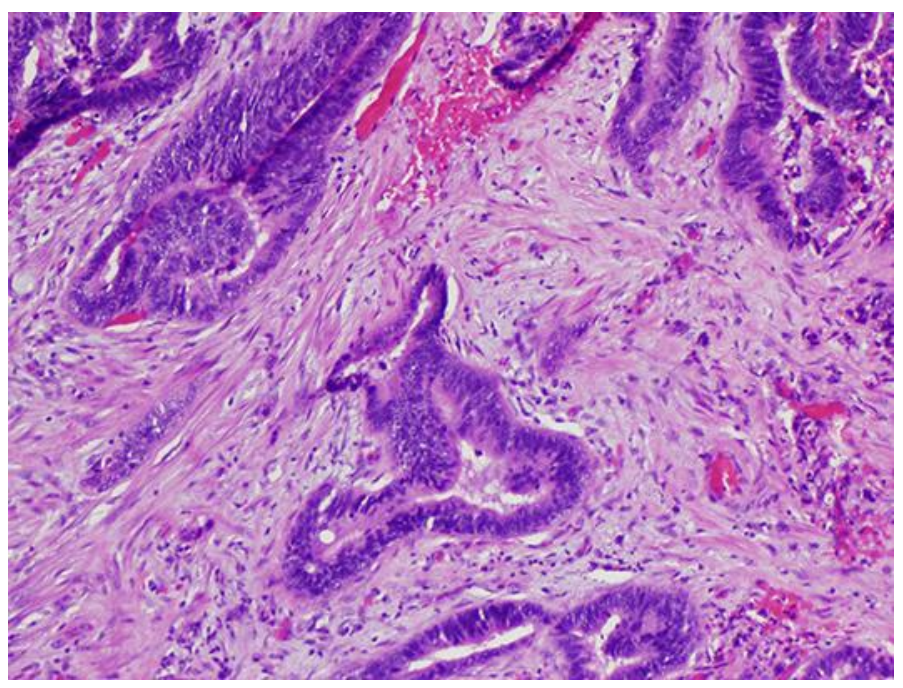

Fig. 3. HE stain $(\times 20)$ showing irregular invasive glands with surrounding desmoplasia consistent with adenocarcinoma arising from tubulovillous adenoma. 